\title{
Guest editorial: Special issue on hedge funds
}

\author{
Vikas Agarwal
}

Published online: 23 April 2011

(C) Springer Science+Business Media, LLC 2011

\section{Introduction}

Hedge funds have gained significant importance in capital markets across the world and are a subject of constant media attention. However, due to the limited regulatory and disclosure requirements for hedge funds, there is a need for better understanding of these investment vehicles that have become a significant part of the financial services industry. The five articles in this special issue are aimed towards achieving this objective. These articles cover important topical areas related to hedge funds including response of hedge funds to recent financial crisis, modeling the risk-adjusted performance of hedge funds, role of hedge funds in corporate governance, design of optimal compensation contract for hedge fund managers, and examination of hedge funds' activities in the primary lending market. I am now going to briefly describe each of the articles included in this issue.

In the first paper titled "The Financial Crisis and Hedge Fund Returns", author Nicolas P.B. Bollen asks an important question: Can we learn something about the onset of financial crisis from the changes in strategies and cross-sectional return distribution of hedge funds? Bollen finds intriguing answers to this question. There is a substantial increase in the explanatory power from linear factor models during the crisis period for two reasons. First, hedge funds move away from idiosyncratic strategies to investing in more liquid assets using traditional investment strategies. Second, there is an increase in the correlation across different asset markets in the wake of the financial crisis. Moreover, Bollen shows discontinuity in hedge fund returns, suggesting that funds avoid reporting losses during the financial crisis to prevent large-scale withdrawal by investors. The findings in this paper should be important in understanding the systemic risk and operational risk associated with hedge fund activities.

\footnotetext{
V. Agarwal $(\varangle)$

Georgia State University, Atlanta, GA, USA

e-mail: vagarwal@gsu.edu
} 
The second paper in this issue is titled "The Option CAPM and The Performance of Hedge Funds". Authors Antonio Diez de los Rios and René Garcia address perhaps one of the most important questions in the hedge fund industry related to the investment performance of hedge funds. They estimate a piecewise-linear stochastic discount factor using generalized method of moments. After accounting for nonlinearities in hedge fund returns and availability of public information to the fund managers, using index level data, they show positive risk-adjusted performance for the overall hedge fund index, equity-market neutral strategy, and the global macro strategy. These findings are clearly of interest to investors attracted to hedge funds in quest of absolute returns.

The third paper by Nicole M. Boyson and Robert M. Mooradian, titled "Corporate Governance and Hedge Fund Activism" examines the foray of hedge funds into activism to generate returns for their investors. The authors find that not only do the hedge fund investors benefit from the activities of activist hedge funds; the firms that these funds target also gain in terms of short-term stock performance and long-term operating performance. The paper shows that hedge funds tend to target small firms with poor recent stock performance and low growth opportunities but strong operating performance. This finding is in contrast to prior literature that documents other activist institutional investors targeting operationally distressed firms. Interestingly, authors Boyson and Mooradian also provide evidence on the channel of improving the performance of target firms through reduction in their excess cash positions to mitigate the agency costs associated with free cash flows. Taken together, this paper makes an important contribution in understanding how hedge funds use corporate governance as a way to create value for the funds' shareholders.

The next paper by Gong Zhan is titled "Manager Fee Contracts and Managerial Incentives". This paper addresses a challenging issue of optimal compensation contract for hedge fund managers. Author Zhan shows that the option-like performance fee contract is suboptimal compared to the symmetric performance fee contract. The paper shows that the high-watermark feature in the compensation contracts can minimize the problem of suboptimal contracts but cannot eliminate it. High-water mark feature seems to help only when the fund is not too much underwater and when the manager is skilled. In addition, author Zhan provides evidence on the importance of co-investment by hedge fund managers that helps align the interests of the investors with the managers, as well as provide incentives to the managers to exert effort. This paper has important implications for design of the optimal compensation contract of hedge fund managers and should be of interest to both regulators and investors that care about the risks and performance of hedge funds.

The final paper by Vikas Agarwal and Costanza Meneghetti, titled "The Role of Hedge Funds as Primary Lenders" examines the activities of hedge funds in the primary loan market. Authors Agarwal and Meneghetti show that hedge funds serve as lenders of last resort to firms with lower profitability, poor credit quality, and higher asymmetric information. The authors find that subsequent to borrowing from hedge funds, there is an improvement in the profitability and creditworthiness of the firms. The market reaction to hedge funds loans is positive around the announcement date, which provides corroborating evidence on these loans being beneficial for borrowing firms. This paper sheds light on the role of hedge funds investing in financially constrained firms that cannot access capital markets or borrow from banks. 